\title{
Efektifitas Papercraf Terhadap Kemampuan Motorik Halus
}

\author{
Hafiza Rosa ${ }^{1}$, Nurhafizah ${ }^{2}$, Yulsyofriend ${ }^{3}$ \\ Program Studi PG-PAUD Fakultas IImu Pendidikan \\ Universitas Negeri Padang \\ Email : hafizarosa94@gmail.com
}

\begin{abstract}
Abstrak
Penelitian ini bertujuan untuk mengetahui efektifitas Papercraft dalam mengembangkan motorik halus anak di TK Raudhatul Jannah. Jenis penelitian yang digunakan adalah metode kuantitatif dengan jenis eksperimen atau penelitian quashi experimental (eksperimen semu) dengan menggunakan Pepercraft. Hasil penelitian ini diperoleh nilai ratarata, nilai yang diperoleh dari eksperimen yang menggunakan Papercraft untuk kemampuan motorik halus anak, nilai rata-ratanya lebih tinggi(89.18) dibandingkan dengan kelompok kontrol (79.72) yang menggunakan Origami. Berdasarkan perhitungan t-test diperoleh bahwa $t_{\text {hitung }}$ lebih besar dari $t_{\text {tabel }}$ menunjukkan bahwa terdapat pengaruh yang signifikan terhadap kemampuan motorik halus anak. Dengan demikian disimpulkan bahwa dengan menggunakan Pepercraft sangat efektif dalam mengembangkan motorik halus anak di TK Raudhatul Jannah.
\end{abstract}

Kata kunci: Pepercraft, kemampuan motorik halus

\section{PENDAHULUAN}

Pendidikan adalah usaha sadar dan terencana untuk mewujudkan suasana belajar dan proses pembelajaran agar peserta didik secara aktif mengembangkan potensi dirinya. Untuk menciptakan generasi yang berkualitas, pendidikan harus dilakukan sejak usia dini melalui penyelenggaraan pendidikan anak usia dini (PAUD). Pendidikan ini diupayakan untuk mengoptimalkan masa emas (golden age) pada anak, agar anak tumbuh menjadi individu yang cerdas secara kognitif, cakap secara afektif dan terampil secara psikomotor.

Berdasarkan Undang-undang Nomor 20 Tahun 2003 tentang Sistem Pendidikan Nasional Bab I Pasal 1 Butir 14 dinyatakan bahwa "Pendidikan Anak Usia Dini adalah upaya pembinaan yang ditujukan kepada anak sejak lahir sampai enam tahun yang dilakukan melalui pemberian rangsangan pendidikan untuk membantu pertumbuhan perkembangan jasmani dan rohani agar anak memiliki kesiapan memasuki pendidikan lebih lanjut". Sedangkan pada pasal 28 tentang 
menuntun anak-anak dengan menyediakan bahan-bahan yang tepat, tetapi yang terpenting agar dapat memahami sesuatu, ia harus membangun pengertian itu sendiri, dan ia harus menemukannya sendiri Salah satu bentuk lembaga pendidikan anak usia dini adalah Taman Kanak-Kanak (TK) yang menyelenggarakan program pendidikan bagi anak berumur 4-6 tahun. Anak usia Taman Kanak-kanak merupakan tahap yang sangat penting dan berharga sehingga dinamakan sebagai masa pembentukan pada periode kehidupan manusia. Tujuan Pendidikan di Taman Kanak-kanak yaitu untuk mengembangkan berbagai potensi anak sejak dini sebagai persiapan untuk hidup dan dapat menyesuaikan diri dengan lingkungannya.

Salah satu aspek perkembangan yang perlu distimulasikan di Taman Kanak-kanak adalah aspek motorik. Kemampuan dasar untuk aspek motorik mempunyai kompetensi dasar agar anak mampu melakukan aktifitas fisik secara terkoordinasi dalam kelenturan dan persiapan untuk menulis, keseimbangan, kelincahan dan melatih keberanian. Pengembangan aspek motorik bertujuan untuk memperkenalkan dan melatih motorik kasar dan motorik halus anak. Aspek motorik terbagi menjadi dua yaitu motorik kasar dan motorik halus. Gerakan motorik kasar adalah berbagai gerakan yang melibatkan otot-otot besar dan sendi-sendi, seperti: meloncat, memanjat, melempar, berdiri, jongkok, berlari dan sebagainya. Sedangkan gerakan motorik halus adalah berbagai gerakan yang melibatkan jari jemari, seperti menulis, melukis, menggambar, menggunting, melipat, menjahit, menganyam, dan meronce.

Anak usia Taman Kanak-kanak khususnya kelompok B diharapkan dalam pengembangan motorik halusnya dengan tingkat capaian perkembangan yaitu anak bisa menggambar sesuai gagasannya, anak bisa meniru bentuk, anak mampu melakukan eksplorasi dengan berbagai media dan kegiatan, anak bisa menggunakan alat tulis dengan benar, anak mampu menggunting sesuai dengan pola, anak bisa menempel gambar dengan tepat, serta anak mampu mengkreasikan diri melalui gerakan menggambar secara detail. Oleh karena itu penulis tertarik melakukan penelitian dengan judul "Efektifitas Keterampilan Papercraft terhadap kemampuan motorik halus di Taman Kanak-kanak Raudhatul Jannah Lapai Pariaman.

Menurut Sumantri (2005:143) menyatakan keterampilan motorik halus adalah pengorganisasian penggunaan sekelompok otot-otot kecil seperti jari-jemari dan tangan yang sering membutuhkan kecermatan dan koordinasi mata dan tangan, keterampilan yang mencakup pemanfaatan dengan alat-alat untuk bekerja dan objek yang kecil atau pengontrolan terhadap mesin misalnya mengetik, menjahit, dll. Sedangkan Menurut Yamin dan Jamilah (2013: 101) kemampuan motorik halus tangan 
mengembangkan kemampuan anak dalam menggunakan jari-jarinya, khusunya ibu jari dan jari telunjuk.

Berdasarkan pendapat di atas dapat disimpulkan bahwa kemampuan motorik halus merupakan kemampuan dalam menggerakan otot-otok kecil seperti jari-jemari khususnya jari jempol dan telunjuk yang sering membutuhkan kecermatan dan koordinasi mata dan tangan sehingga anak dapat melakukan kegiatan seperti menggunting, menulis, menggambar dan lain-lain.

Media merupakan salah satu alat penyampai materi kepada peserta didik. Media tidak hanya dipahami sebagai alat peraga, tetapi juga sebagai pembawa informasi atau pesan kepada peserta didik. Menurut Hamidjojo dalam Arsyad (2013: 4) bahwa media adalah semua bentuk perantara yang digunakan oleh manusia untuk menyampaikan atau penyebar ide, gagasan, atau pendapat yang dikemukakan itu sampai kepada penerima yang dituju. Sedangkan Menurut Gerlach \& Ely dalam Latif, dkk (2013:151) media adalah manusia, materi, atau kejadian yang membangun kondisi yang membuat siswa mampu memperoleh pengetahuan keterampilan, atau sikap. Dalam pengertian ini, guru, buku teks, dan lingkungan seolah merupakan media..

Jadi, media adalah semua bentuk perantara yang digunakan manusia untuk menyampaikan atau penyebar ide, gagasan atau pendapat agar penerima memperoleh keterampilan pengetahuan atau sikap.

Menurut Fakhruddin (2010: 124) aspek-aspek keterampilan seni yaitu, 1) Keterampilan gerak sederhana, diperoleh anak melalui aktivitas seperti menggunting, menempelkan, memegang sikat, mewarnai dengan krayon dan memegang pensil, 2) Koordinasi tangan dan mata, yang memungkinkan anak untuk melakukan aktivitas seperti menggunting mengikuti garis pola, memencet lem dari botol sampai meletakkan pada daerah yang akan dilem, menata semaian bibit bunga matahari dihalaman sekolah dan sebagainya, 3) Keterampilan memecahkan masalah, 4) Keterampilan berbahasa. Pada saat anak melakukan aktivitas seni secara bebas bersama teman-temannya, mereka akan saling berinteraksi dan berkomunikasi. Berarti mereka saling berbicara tentang karyanya, pengalamannya, atau warna pilihannya.

Berdasarkan pendapat di atas dapat disimpulkan bahwa aspekaspek keterampilan seni yaitu keterampilan gerak sederhana, koordinasi tangan dan mata, keterampilan memcahkan masalah serta keterampilan berbahasa sehingga anak bisa beriinteraksi dan berkomunikasi dengan orang-orang sekitarnya.

Menurut Azad (2011: 6) Papercraft atau Papertoy yaitu seni kerajinan yang menggunakan bahan dasar kertas dengan bentuk tiga 
dimensi. Berbeda dengan Origami (seni melipat kertas dari jepang), papercraft memerlukan tambahan, yaitu pemotongan (menggunakan gunting atau cutter) dan pengeleman

\section{METODE PENELITIAN}

Berdasarkan permasalahan yang diteliti maka jenis penelitian ini adalah metode kuantitatif dengan jenis eksperimen atau penelitian quashi experimental (eksperimen semu). Menurut Sugiyono (2012:7) penelitian Eksperimen merupakan suatu penelitian yang berusaha mencari pengaruh variabel tertentu terhadap variabel yang lain dalam kondisi yang terkontrol ketat, mencari hubungan sebab-akibat (hubungan kausal) antara dua faktor yang sengaja ditimbulkan oleh peneliti dengan mengeliminasi atau mengurangi atau menyisihkan faktor-faktor lain yang mengganggu. dengan kata lain penelitian eksperimen ini berguna untuk mencoba suatu yang baru yang digunakan, dilaksanakan, dan dikembangkan dalam kehidupan yang sebenarnya.

Populasi dalam penelitian ini adalah TK Raudhatul Jannah yang beralamat di jalan Imam Bonjol No. 88, desa Cimparuah Lapai, Kec. Pariaman Tengah, Kota Pariaman. TK Raudhatul Jannah TK ini di bawah naungan Yayasan Mifthah Jannah yang beralamat di lokasi yang sama.

Adapun teknik pengambilan sampel yang dilakukan dalam penelitian adalah teknik cluster sampling, yaitu teknik penentuan sampel apabila populasi cukup besar, sehingga perlu dibuat beberapa kelas, atau kelompok..

Berdasarkan konsep di atas, maka kelompok yang akan dijadikan dalam penelitian ini adalah kelompok B1 dan B3. Dimana kelompok B3 dijadikan kelas eksperimen dan kelompok B1 dijadikan kelas kontrol dengan pertimbangan jumlah anak kedua kelompok sama yaitu masingmasing 11, usia anak yang sama, tingkat kemampuan anak yang sama, fasilitas belajar yang sama, rekomendasi dari guru kedua kelompok dan kepala TK Raudhatul Jannah.

Instrumen penelitian yang digunakan dalam penelitian ini adalah tes. Tes dikatakan valid apabila tes itu dapat mengukur apa yang hendak diukur. Instrumen ini menggunakan skala likert untuk penilaiannya. Dengan kriteria penilaian yaitu Sangat Baik diberi skor 4 (SB), Baik diberi skor 3 (B), Tidak Baik diberi skor 2 (TB), Sangat Tidak Baik diberi skor 1 (STB).

Tes yang peneliti gunakan berupa tes Perbuatan. Tes perbuatan adalah tes yang menuntut jawaban dari peserta didik dalam bentuk perilaku, tindakan atau perbuatan." Jadi anak berbuat sesuai dengan perintah atau pertanyaan yang diberikan. 
Menurut Arikunto (2010:211) validitas adalah suatu ukuran yang menunjukkan tingkat-tingkat kevalidan atau kesalihan sesuatu instrumen. Suatu instrumen yang valid atau sahih mempuyai validitas tinggi. Sebaliknya, instrumen yang kurang valid berarti memiliki validitas rendah. Sebuah instrumen dikatakan valid apabila dapat mengungkap data dari variabel yang diteliti secara tepat. Tinggi rendahnya validitas instrumen menunjukkan sejauh mana data yang terkumpul tidak menyimpang dari gambaran tentang validitas yang dimaksud. Reliabilitas tes merupakan suatu ukuran ketepatan suatu tes apabila diteskan ke objek yang sama. Untuk menentukan reliabilitas tes dipakai rumus alpha.

Teknik analisis data yang digunakan dalam penelitian ini adalah membandingkan perbedaan dari dua rata-rata nilai, sehingga dilakukan dengan uji t (t-tes). Namun sebelum itu, terlebih dahulu melakukan uji normalitas dan uji homogenitas.

Untuk melakukan analisis perbedaan tersebut, perlu dilakukan uji normalitas. Menurut Syafril (2010:211), Uji normalitas digunakan untuk mengetahui apakah data yang akan diolah berasal dari data berdistribusi normal. Uji normalitas dilakukan sebelum mengolah data dengan teknik korelasi productmoment, regresi, t-test, dan anava dan sebagainya. Teknik yang sering digunakan untuk uji normalitas data adalah uji Liliefors.

Sebelum data diolah, agar diketahui suatu data berdistribusi normal atau tidak maka dilakukan uji Liliefors terlebih dahulu. Salah satu teknik yang sering digunakan untuk menguji homogenitas varians populasi adalah dengan menggunakan uji Bartlett. Jika sudah diketahui sebuah data berdistribusi normal dan bersifat homogen baru dilakukan analisis data sesuai dengan teknik analisis yang telah dilakukan. Yaitu dengan mencari perbandingan dengan menggunakan t-test. Menguji data yang telah diperoleh tersebut dengan rumus t-test.

\section{HASIL}

Untuk menarik kesimpulan dari hasil penelitian, dilakukan uji hipotesis dengan menggunakan uji t. Sebelum melakukan uji t terlebih dahulu dilakukan uji normalitas dan uji homogenitas terhadap hasil penelitian.

Berdasarkan hasil penelitian anak yaitu kemampuan motorik halus anak pada kelas eksperimen dan kelas kontrol, diperoleh hasil bahwa kemampuan motorik halus anak di kelas eksperimen (kelompok B3) lebih tinggi dibandingkan pada kelas kontrol (kelompok B1).

Berdasarkan uji normalitas kelompok eksperimen dan kelompok kontrol diperoleh harga $L_{o}$ dan $L_{t}$ pada taraf nyata 0,05 untuk $N=11$ seperti tabel berikut: 
Tabel 1. Hasil Perhitungan Pengujian Liliefors Pre-test Kelompok Eksperimen dan Kelompok Kontrol

\begin{tabular}{|c|l|c|c|c|c|c|}
\hline No & \multicolumn{1}{|c|}{ Kelas } & $\mathbf{N}$ & $\mathbf{A}$ & $\mathbf{L}_{\mathbf{0}}$ & $\mathbf{L}_{\mathbf{t}}$ & Keterangan \\
\hline 1 & Eksperimen & 11 & 0.05 & 0.1694 & 0.249 & Normal \\
\hline 2 & Kontrol & 11 & 0.05 & 0.1364 & 0.249 & Normal \\
\hline
\end{tabular}

Berdasarkan tabel 1 terlihat bahwa kelompok eksperimen nilai $L_{\text {hitung }} \mathbf{0 . 1 6 9 4}$ lebih kecil dari $L_{\text {tabel }} \mathbf{0 . 2 4 9}$ untuk $\alpha 0,05$. Dengan demikian nilai kelompok eksperimen berasal dari data yang berdistribusi normal. Untuk kelompok kontrol diperoleh $L_{\text {hitung }} \mathbf{0 . 1 3 6 4}$ lebih kecil dari $L_{\text {tabel }} \mathbf{0 . 2 4 9}$ untuk $\alpha 0,05$. Ini berarti bahwa data kelompok kontrol berasal dari data yang berdistribusi normal.

Pengujian persyaratan yang kedua adalah pengujian homogenitas dengan menggunakan uji Barlett. Pengujian ini bertujuan untuk mengetahui apakah data berasal dari kelompok yang homogen, antara kelompok eksperimen dan kelompok kontrol. Jika chi kuadrat hitung <chi kuadrat tabel berarti data berasal dari kelompok yang homogen.

Tabel 2. Hasil Perhitungan Uji Homogenitas Kelas Eksperimen dan Kelas Kontrol

\begin{tabular}{|c|c|c|c|c|}
\hline Kelas & $A$ & $\chi_{\text {hitung }}^{2}$ & $\chi_{\text {table }}^{2}$ & Kesimpulan \\
\hline Eksperimen & \multirow{2}{*}{0,05} & \multirow{2}{*}{0.167} & \multirow{2}{*}{3.841} & \multirow{2}{*}{ Homogen } \\
\hline Kontrol & & & & \\
\hline
\end{tabular}

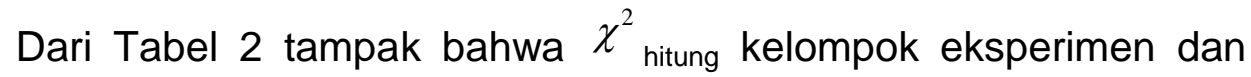
kelompok kontrol lebih kecil dari $\chi_{\text {tabel }}^{2}\left(\chi_{\text {hitung }}^{2} \chi_{\text {tabel }}^{2}\right.$, berarti kelompok eksperimen dan kelompok kontrol memiliki varians yang homogen..

Setelah dilakukan uji normalitas dan uji homogenitas, diketahui bahwa kedua kelas sampel berdistribusi normal dan mempunyai varians homogen. Maka dapat dilanjutkan dengan pengujian hipotesis dengan menggunakan teknik t-tes.

Tabel 4. Hasil Perhitungan Pengujian dengan t-test

\begin{tabular}{|c|l|c|c|c|c|c|}
\hline No & Kelompok & $\mathbf{N}$ & $\begin{array}{c}\text { Hasil } \\
\text { Rata-rata }\end{array}$ & t hitung & $\begin{array}{c}\mathbf{t} \text { table } \\
\mathbf{\alpha} \mathbf{0 , 0 5}\end{array}$ & Keputusan \\
\hline $\mathbf{1}$ & Eksperimen & 11 & 60.18 & 0.919 & 2.085696 & Terima $\mathrm{H}_{0}$ \\
\hline $\mathbf{2}$ & Kontrol & 11 & 58.00 & & \\
\hline
\end{tabular}

T tabel untuk taraf nyata $\alpha=0.05$ (5\%) dengan df sebesar 20 adalah $=2.085696$. Dengan demikian, dapat diketahui bahwa pada taraf nyata $\alpha=0.05(5 \%)$, $t_{\text {hitung }}$ lebih kecil daripada $t_{\text {tabel }}(0.958<2.05553)$. jadi, dapat disimpulkan bahwa tidak terdapat perbedaan yang signifikan antara hasil pre-test (kemampuan awal) kemampuan motorik halus anak di kelas eksperimen dan kelas kontrol di TK Raudhatul Jannah. 
Data post test penelitian kelas eksperimen dan kelas kontrol diolah untuk menentukan uji normalitas. Pada uji normalitas ini digunakan uji Liliefors seperti yang dikemukakan pada teknik analisis data. Analisis normalitas pada kelompok eksperimen dan kelompok.

Berdasarkan uji normalitas kelompok eksperimen dan kelompok kontrol diperoleh harga $L_{0}$ dan $L_{t}$ pada taraf nyata 0,05 untuk $N=11$ seperti pada tabel berikut:

Tabel 5. Hasil Perhitungan Pengujian Liliefors Kelompok Eksperimen dan Kelompok Kontrol

\begin{tabular}{|c|c|c|c|c|c|c|}
\hline No & Kelas & $\mathbf{N}$ & $\mathbf{A}$ & $\mathbf{L}_{\mathbf{0}}$ & $\mathbf{L}_{\mathbf{t}}$ & Keterangan \\
\hline 1 & Eksperimen & 11 & 0.05 & 0.1562 & 0.249 & Normal \\
\hline 2 & Kontrol & 11 & 0.05 & 0.1619 & 0.249 & Normal \\
\hline
\end{tabular}

Berdasarkan tabel terlihat bahwa kelompok eksperimen nilai $L_{\text {hitung }}$ 0.1562 lebih kecil dari $L_{\text {tabel }} \mathbf{0 . 2 4 9}$ untuk $\alpha \mathbf{0 . 0 5}$. Dengan demikian nilai kelompok eksperimen berasal dari data yang berdistribusi normal. Untuk kelompok kontrol diperoleh $L_{\text {hitung }} \mathbf{0 . 1 6 1 9}$ lebih kecil dari $L_{\text {tabel }} \mathbf{0 . 2 4 9}$ untuk a 0.05. ini berarti bahwa data kelompok kontrol berasal dari data yang berdistribusi normal.

Pengujian persyaratan yang kedua adalah pengujian homogenitas dengan menggunakan uji Barlett. Pengujian ini bertujuan untuk mengetahui apakah data berasal dari kelompok yang homogen, antara kelompok eksperimen dan kelompok kontrol. Jika chi kuadrat hitung < chi kuadrat tabel berarti data berasal dari kelompok yang homogen.

Hasil perhitungan diperoleh $\mathrm{X}^{2}$ hitung sebesar 0.343 seperti yang dituliskan dalam tabel berikut :

Tabel 6. Hasil Perhitungan Uji Homogenitas Kelas Eksperimen dan Kelas Kontrol

\begin{tabular}{|c|c|c|c|c|}
\hline Kelas & $\mathrm{A}$ & $\chi_{\text {hitung }}^{2}$ & $\chi_{\text {table }}^{2}$ & Kesimpulan \\
\cline { 1 - 5 } Eksperimen & \multirow{2}{*}{0,05} & 0.1605 & 3.841 & Homogen \\
\cline { 1 - 1 } Kontrol & & & & \\
\hline
\end{tabular}

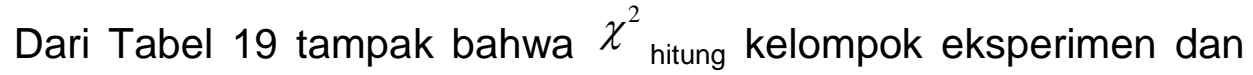
kelompok kontrol lebih kecil dari $\chi_{\text {tabel }}^{2}\left(\chi_{\text {hitung }}^{2} \chi_{\text {tabel }}^{2}\right.$, berarti kelompok eksperimen dan kelompok kontrol memiliki varians yang homogen. Setelah dilakukan uji normalitas dan uji homogenitas, diketahui bahwa kedua kelompok sampel berdistribusi normal dan mempunyai varians homogen. Maka dapat dilanjutkan dengan pengujian hipotesis dengan menggunakan teknik t-test. 
Dari hasil uji hipotesis dengan menggunakan t-test diperoleh $\boldsymbol{t}_{\text {hitung }}$ sebesar 2.9203. Sementara $\boldsymbol{t}_{\text {tabel }}$ untuk taraf nyata $\alpha 0.05(5 \%)$ dengan $\mathrm{df}$ sebesar 20 adalah $=$ 2.08596. Jadi dapat diketahui kalau $\boldsymbol{t}_{\text {hitung }}$ lebih besar daripada $t_{\text {tabel }}$ pada taraf nyata a 0.05 (5\%) yaitu 2.9203> 2.08596. jadi, dapat disimpulkan bahwa $\mathrm{H}_{\mathrm{a}}$ diterima yaitu terdapat pengaruh yang signifikan dari penggunaan Papercraft terhadap kemampuan motorik halus anak di TK Raudhatul Jannah.

Tabel 8. Hasil Perhitungan Pengujian dengan t-test

\begin{tabular}{|c|l|c|c|c|c|c|}
\hline No & Kelompok & $\mathbf{N}$ & $\begin{array}{c}\text { Hasil } \\
\text { Rata-rata }\end{array}$ & t hitung & $\begin{array}{c}\mathbf{t} \text { table } \\
\mathbf{\alpha} \mathbf{0 , 0 5}\end{array}$ & Keputusan \\
\hline $\mathbf{1}$ & Eksperimen & 11 & 89.18 & 2.9203 & 2.0859 & Tolak $\mathrm{H}_{0}$ \\
\hline $\mathbf{2}$ & Kontrol & 11 & 79.72 & & \\
\hline
\end{tabular}

Berdasarkan tabel di atas dapat disimpulkan bahwa Ha diterima yaitu terdapat pengaruh yang signifikan dari penggunaan Papercraft terhadap kemampuan motorik halus anak di TK Raudhatul Jannah. Setelah dilakukan perhitungan nilai pre-test dan post-test kelompok eksperimen dan kontrol maka selanjutnya akan dilakukan perbandingan antara nilai pre-test dan nilai post-test, yang tujuannya untuk melihat apakah ada perbedaan nilai post-test dan nilai pre-test anak.

Perbandingan hasil perhitungan nilai pre-test dan nilai post-test. Pada pre-test nilai tertinggi yang diperoleh anak kelas eksperimen yaitu 70 dan nilai terendah 54, dengan rata-rata 60,18 sedangkan pada kelas kontrol nilai tertinggi yang diperoleh anak yaitu 70 dan nilai terendah 50 dengan rata-rata 58. Pada post-test nilai tertinggi yang diperoleh anak kelas eksperimen yaitu 95 dan nilai terendah 75 dengan rata-rata 89,18 sedangkan pada kelas kontrol post-test nilai tertinggi yang diperoleh anak yaitu 92, dan nilai terendah 62 dengan rata-rata 79,72

Perbandingan hasil perhitungan nilai pre-test dan post test terlihat pada nilai tertinggi dan nilai terendah yang diperoleh anak dan terlihat pada rata-rata kelas eksperimen dan kelas kontrol pada post-test dimana pada post-test rata-rata menjadi lebih meningkat dari rata-rata pre-test setelah dilakukan treatment

Untuk lebih jelasnya dapat dilihat grafik 1. 


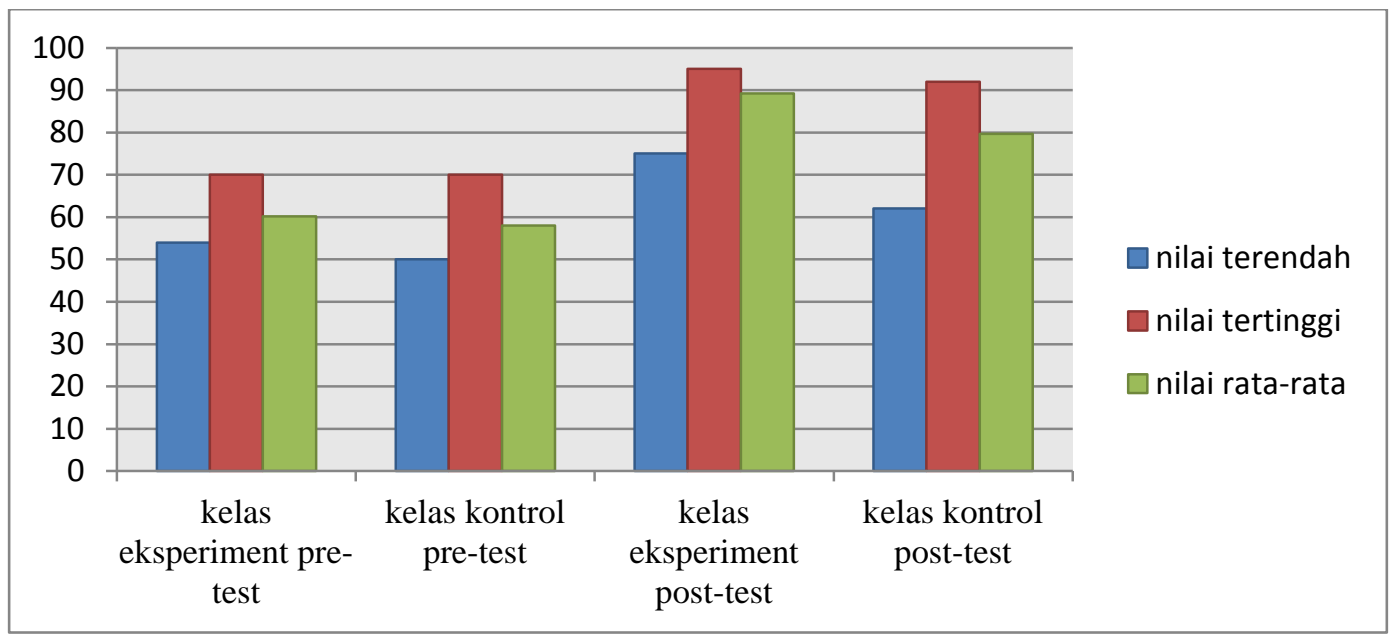

Grafik 1.Data Perbandingan Hasil Pre-Test dan Post-Test kemampuan motorik halus Anak Kelompok Eksperimen dan Kelompok Kontrol

Pada pembelajaran dengan menggunakan Pepercraft ini, guru berfungsi sebagai fasilitator, yang bertugas memberikan pengarahan dan contoh kepada anak. Keaktifan anak dalam membuat Papercraft dan menggunakan jari-jemari lebih ditekankan pada pembelajaran ini. Dengan adanya pembelajaran ini, kemampuan motorik halus anak dapat dikembangkan.

Dari uraian di atas, sangat jelas bahwa penggunaan Pepercraft efektif dalam mengembangkan motorik halus anak. Hal ini terlihat dari perolehan nilai kemampuan motorik halus anak kelas eksperimen terdapat pengaruh dari pada kelas kontrol yang menggunakan media konvensional (melukis dengan kertas)

\section{PEMBAHASAN}

Berdasarkan hasil kemampuan motorik halus anak di kelas eksperimen dan kelas kontrol pada Pre-Test diperoleh angka rata-rata kelas eksperimen lebih besar dari pada angka rata-rata kelas kontrol. Pada hasil analisis data yang telah dilakukan terlihat bahwa thitung lebih kecil dibandingkan dengan $t_{\text {tabel, }}$ maka dapat dikatakan bahwa hipotesis $\mathrm{H}_{\mathrm{a}}$ ditolak atau $\mathrm{H}_{0}$ diterima. Jadi dapat disimpulkan bahwa tidak terdapat perbedaan yang signifikan antara kemampuan motorik halus anak kelas eksperimen dan kelas kontrol.

Kemudian, berdasarkan hasil kemampuan motorik halus anak di kelas eksperimen dan kelas kontrol pada post-test diperoleh angka ratarata kelas eksperimen lebih besar dari pada angka rata-rata kelas kontrol. Pada hasil analisis data yang telah dilakukan terlihat bahwa $t_{\text {hitung }}$ lebih besar dibandingkan dengan $t_{\text {tabel }}$ Dengan demikian dapat dikatakan bahwa hipotesis $\mathrm{H}_{\mathrm{a}}$ diterima atau $\mathrm{H}_{0}$ ditolak. Jadi, dapat disimpulkan bahwa 
terdapat pengaruh yang signifikan dari penggunaan Papercraft terhadap kemampuan motorik halus anak di TK Raudhatul Jannah.

Kemampuan motorik halus adalah kemampuan menggunakan otot-otot kecil seperti jari-jemari dan tangan yang membutuhkan koordnasi mata dan tangan, kemampuan pemanfaatan dengan alat-alat untuk bekerja. Pengembangan keterampilan motorik halus akan berpengaruh terhadap kesiapan anak dalam menulis serta kegiatan melatih koordinasi antara tangan dengan mata. Sehingga, diperlukan suatu upaya dalam mengembangkan kemampuan motorik halus anak yaitu, dengan menghadirkan media yang menarik, interaktif dan menyenangkan, salah satunya media Papercraft.

Papercraft merupakan salah satu alat bantu dalam menciptakan pembelajaran yang lebih variatif. Dengan penggunaan media baru bagi anak, akan memacu semangat anak saat belajar. Menurut pendapat Azad (2011: 6) Papercraft yaitu seni kerajinan yang menggunakan bahan dasar dan menarik. Pada saat peneliti menggunakan Papercraft ini di dalam kelas (B3) TK Raudhatul Jannah, semua anak terlihat antusias dan semangat untuk mencobanya karena pembelajaran menggambar menggunakan Papercraft ini terbilang baru bagi anak. Melalui Papercraft anak mampu membuat mengembangkan kemampuan motorik halus, karena pada pembuatan Papercraft anak melakukan kegiatan mewarnai, menggunting, melipat dan menempel. Sedangkan di Kelas kontrol yang menggunakan origami anak kurang antusias. Hal ini terjadi karena origami sudah sering digunakan dan hasilnya yang dua dimensi yang menyebabkan anak kurang antusas dan cepat bosan. Hal ini mengakibatkan hanya sebagian anak yang berkembang kemampuan motorik halusnya.

Berdasarkan uraian diatas dapat dilihat bahwa hasil kemampuan motorik halus anak di kelas eksperimen lebih baik dari pada hasil kemampuan motorik halus anak di kelas kontrol, karena rata-rata nilai anak kelas eksperimen yang lebih tinggi dari pada kelas kontrol. Maka dapat disimpulkan bahwa penggunaan Papercraft mempengaruhi kemampuan motorik halus anak.

\section{SIMPULAN}

Berdasarkan hasil penelitian dan pembahasan yang telah dikemukakan pada bab terdahulu, maka pada bagian ini akan dikemukakan beberapa simpulan dan saran terhadap hasil penelitian. Hasil penelitian yang diperoleh terdapat perbedaan hasil kemampuan motorik halus anak di TK Raudhatul Jannah yang signifikan yaitu antara kelas eksperimen (B3) dan kelas kontrol (B1). Hal ini membuktikan bahwa dengan menggunakan Pepercraft dapat mempengaruhi kemampuan 
motorik halus anak. Sehingga nilai rata-rata yang diperoleh dari kelas eksperimen lebih tinggi $(89,18)$ dibandingkan kelas kontrol $(79,72)$.

Dari hasil uji hipotesis didapat $t_{\text {hitung }}>t_{\text {tabel }}$ dimana 2.9203>2.08596 yang dibuktikan dengan taraf signifikansi $\alpha 0,05$ ini berarti terdapat perbedaan yang signifikan antara hasil kemampuan motorik halus anak pada kelas eksperimen yang menggunakan Papercraft dengan kelas kontrol yang menggunakan media konvensional (Origami).

Dengan menggunakan Pepercraft terbukti dapat memberikan pengaruh yang signifikan terhadap kemampuan motorik halus anak di TK Raudhatul Jannah. Penggunaan Pepercraft diharapkan dapat dipergunakan sebagai alternatif media pembelajaran bagi guru dalam mengajar, sehingga dapat meningkatkan kualitas pembelajaran.

Kepada Kepala Sekolah TK diharapkan agar lebih peduli dalam memberikan motivasi dan arahan serta pelatihan maupun pendidikan tentang pentingnya penggunaan variasi media pembelajaran khususnya pada kemampuan motorik halus anak. Penelitian lanjutan, hasil penelitian ini dapat menjadi sumber bacaan/ literature bagi peneliti lain untuk mengembangkan penelitian yang lama.

\section{DAFTAR PUSTAKA}

Arikunto, Saharsimi. 2010. Prosedur Penelitian Suatu Pendekatan Praktik. Jakarta. Rineka Cipta

Arsyad, Azhar. 2013. Media Pembelajaran. Jakarta: Rajawali Pers

Azad, Faisal. 2011. Ayo, Membuat Papertoy Cerita Rakyat. Solo: Tiga Serangkai

Fakhruddin, Asef Umar. 2010. Sukses menjadi Guru TK-PAUD

Latif, Mukthar dkk. 2013. Pendidikan Anak Usia Dini (Teori dan Aplikasi).Jakarta: Kencana

Sugiyono, 2012. Metode Penelitin Administrasi. Bandung: Alfabeta

Sumantri. 2005. Model Pengembangan Keterampilan Motorik Anak Usia Dini.

Jakarta : Departemen Pendidikan Nasional Direktorat Jenderal

Pendidikan Tinggi Direktorat Pembinaan Pendidikan Tenaga Kependidikan dan Ketenagaan Perguruan Tinggi

Syafril. 2010. Statistika. Padang: Sukabina Press

Yamin Martinis dan Jamila Sabri Sanan. 2013. Panduan PAUD. Jakarta : Referensi. 